\title{
THE APPLICATION OF INFORMATION AND COMMUNICATION TECHNOLOGY (I.C.T.) IN NIGERIAN ACADEMIC LIBRARIES PROSPECTS AND PROBLEMS
}

BY

MARTHA J. ELISHA

\author{
KASHIM IBRAHIM LIBRARY \\ AHMADU BELLO UNIVERSITY, \\ ZARIA.
}

\begin{abstract}
Academic libraries play a prominent role in providing information services in various forms to researchers, scientist, policy makers, planners etc. A well organized academic library should have I.C.T. to assist both patrons and information professionals in the libraries. This paper highlights the prospects and problems of I.C.T in Nigeria academic libraries. Recommendation for functional I.C.T. in Nigerian academic library has also been given.
\end{abstract}

\section{INTRODUCTION}

Laymen tend to equate the application of ICT in any profession to being "online" meaning connected to the Internet. Although the Internet is an integral part of the ICT, it is not all there is to it. This paper seeks to investigate the many opportunities for the application of ITC in Nigerian academic libraries. It is hoped that the application of ICT in academic libraries will assist both the patrons and the library and information professionals in the libraries.

However, what is the ICT? ICT is an acronym for information and communication Technology but beyond this acronym, "there is not a universally accepted definition of ICT. Why? Because the concepts, methods and applications involved in ICT are constantly evolving on an almost daily basis. It's difficult to keep up with the changes - they happen so fast---- A good way to think about ICT is to consider all the uses of digital technology that already exist to help individuals, businesses and organizations use information. ICT covers any product that will store, retrieve, manipulate, transmit or receive information electronically in a digital form. For example, personal computer, digital television, email, robots “(wwwtutor24.net.2006).

Also, "ICT.... Is an umbrella term that includes any communication device or application encompassing; radio, television, cellular phones, computer and network hardware and software, satellite systems and so on, as well as the various services and applications associated with them such as video conferencing and distance - learning (nHp://search smb.Techtarget.com2006).

From these definitions, some of the application of ICT have become clear such as video conferencing and distance learning, both of which can be facilitated by the academic library. Other applications of the ITC specific to libraries could include: access to online resources on the internet such as e-journals, e-books and emagazines, e-publishing; using CD-ROM for literature searches, access to local or network data bases on LAN (local area network ) or WAN (wide area network), the opportunities for the application of the ITC in an academic library especially in a developing nation like Nigeria seem endless.

The application or use of ICT in Nigerian academic library is justified in that it provides access to learning resources, information and knowledge hitherto inaccessible by reason of distance, resources and the availability of relevant technology.

However, since according to the European Commission, "the importance of ICT lies less in the technology itself in its ability to create greater access to information and communication”. (hHp://searchs mb. Techtarget. 
Com, 2006), there is need especially in a developing nation like ours to examine the prospects for the successful application of ICT in our academic libraries and the challenges these prospects (may) face.

\section{ICT APPLICATION IN NIGERIAN ACADEMIC LIBRARIES: PROSPECT}

Given the great advances being made in the field of communication, there are great possibilities for the application of ICT in academic libraries. In Nigeria, despite the great challenges (some of which are discussed below), there is room for ICT application in the academic libraries in many ways including the following:

\section{A. Online Access to Educational Resources}

Through the Internet, for example, diverse resources could be accessed, transmitted and retrieved. "The Internet brings more information to more people and more people within reach of each other than any other communication vehicle yet invented. (Oniyide P. 103).

Knowing that "ICTs are being continuously updated or introduced and traditional formats are being replaced or supplemented by digital formats (such as ejournals and e-books)." (Ash croft and watts, 2005, p6), there is need for Internet access in the Nigerian academic libraries to enable them key into these online resources, which could be transmitted electronically and thus faster and cheaper.

Another aspect of the internet is the electronic mail (e-mail). "E-mail is a fast, easy and in expensive way to communicate with other Internet users around the world. It is used to obtain important new resources for learning and teaching in schools. It is possible to send out orders to publishers and producers of the learning and teaching materials and equipment. “Oniyide, ibid, P 104).

Through the internet, current ICT has provided a means for Nigerian academic libraries to access online digital resources like online bookshops such as the Amazon" (www.amazon.com.), free online resources such as the wikipedia free encyclopedia (www.wikipedia.com) as well as enable the use of search engines such as "go ogle" (www.go ogle.com) and all the web "(www.alltheweb.com) and free e-mail services such as yahoo mail (www.yahoo.mails.com). Unless Nigerian academic libraries develop a reliable Internet connectivity and via efficient internet service provide' (ISPs), they will be denying both themselves and their patrons access to valuable academic resources outside the libraries.

\section{B. The Digital Reference Services}

"The use of ICT skills spill over into all aspects of library works and the explosion of electronic information delivery has resulted into the need for electronic user support. Over the past few years, a number of electronic reference services have developed in response to this need”. (Ashcroft and Watts, 2005, p. 7).

The digital Reference services, DRS, aim at pooling the resources of various libraries into a common and easily accessible database by which users are given access to information and resources hitherto unavailable in their local libraries. "Collaboration is at the heart of the (DRS) system and ...requires that libraries use it within local groups or join the global consortium if taking it on an individual basis.... these developments indicates the importance of users focus into wider areas of collaboration. The examples also indicate the increasing importance of ICT skills” (Ashcrof and Watts, 2005, pp.7-8).

The use of Digital Reference services has created access to more data online, some examples of which include; All expert (www.allecperts.com). Ask a Librarian (www.Ask-a-librarian.org.UK) and Answers Now (hHp://richland.Lib.Sc.US answer now htm).

In Nigeria, the NuNet, which is a project to connect all the Nigerian Universities on a wide area network and to the Internet, is perhaps the nearest approximation to a digital reference service. NuNet provides dial-up e-mail services to 27 universities and inter-university centers across the country. Unfortunately, "of those Nigerian university libraries surveyed, only 38.5 percent were using NuNet... the collaborative approach is identified as important for digital reference services. The development of Nunet could encourage collaboration between university libraries in Nigeria, which could eventually work towards collaborative digital reference services (Ash croft and watts, 2005 p.9). 
The emphasis should not only be on the university library, but on all other Nigerian academic libraries. The libraries must continue to explore areas of cooperation, such as the sharing of access to this electronic cataloguing system with other academic libraries both within and outside the country. Unless efforts towards a collaborative digital reference services are intensified among the Nigerian academic libraries, any success in ITC application recorded in one cannot easily be accessible to other academic libraries, thus in the long run will work against the effective application of ICT in Nigerian academic libraries.

\section{Manpower Development}

Besides the use of ICT to provide access to educational resources to library patrons, ICT can be used to facilitate on-the-job training and retraining of information professionals. As noted above ICT is developing at a pace very difficult to keep up with, as such there are need for the information professionals to know and follow trends in ICT.

Since "information professionals are being called upon to work dozily with ICT users and providers (including it staff) and to work in collaboration with others in the profession....... Some group of users lack the necessary IT skills to obtain quality information... and information professional will therefore be called upon to act as both educators and intermediaries..... given these circumstances, information professionals are required to have increased teaching and communication skills" (Ash croft and watts, 2005, p.6).

Thus, unless the relevant manpower is developed or acquired within our academic libraries, all advances in ICT application will not be fully utilized. Unfortunately,' too much emphasis has been placed upon the development of ICT information in developing countries and not enough consideration has been given to human resource development .... Stein Muller (2001) suggests that many ICT users are self taught and are capable of developing an understanding of ICTs through the experience of utilizing them. If thus be the case, the countries unable to provide extensive access to ICTs are inevitable marginalized, as they are less likely to produce capable self-taught persons. (Ash croft and watts, 2005, p. 9).
For the Nigerian academic libraries to take full advantage of the opportunities offered by ICT and its application in the library environment it must create extensive access to ICT and relevant tutorial packages on new technology applications, software and software management and CD-ROMs which will enable the ICT professionals within the library setting to install, manage, maintain and repair ICTs easily and to assist other ICT users to maximize the opportunities offered by ICT as well as ensure effective collaboration such as in a digital: reference service.

\section{ICT APPLICATION IN NIGERIAN ACADEMIC LIBRARIES}

\section{PROBLEM}

The problems facing the academic library in Nigeria in particular and Africa at large are both many and serious. As relates to ICT application, Jensen, 2002 and Magara, 2002 (in Ash croft and Watts, 2005, p. 8) argue that "in Africa one in 100 people have access to PC; the few Internet Services Providers are comparatively extensive, power sullies may be unrealiable (even non existent) and telecommunications are sparse with 90 percent of the population living in rural areas having only 50 percent of the telephone lines”.

For clarity, the problems hindering the effective application of ICT in Nigerian academic libraries will be discussed topically as follows:

i. Poor ICT knowledge, there is a severe and pronounced "low level computer literacy among Nigerians” (Okiy, 2005). This makes it difficult for them as users and patrons of academic libraries to make full use of available ICT facilities. This problem is further aggravated by the "shortage of technology literate staff in libraries, the lack of skilled human resources to install and manage technology networks and poor funding to attract such staff or develop such skill in existing staff. [Policy making staff have a] serious lack of awareness of computer capabilities and computer skills are low. (Ash croft and Watts, 2005, p.9).

The poor ICT knowledge among both users and professionals in Nigeria makes it difficult for the academic libraries to go far in 
their application of ICT. Many libraries are "lacking resources and technical support, and staff needing continuously to acquire appropriate training in order to deliver up-to-date services and trouble shoot equipment (Bill and Melinda Gates Foundation, 2005, p8).

Without the relevant ICT skills, the Nigerian ICT professionals are unable to guide the academic library patrons maximize available ICT facilities and explore the opportunities they offer.

\section{ii. Lack of comprehensive ICT policy}

Although no library can be effective without a policy, which sets out aim and objectives, identifies user groups and services and indicates priorities among them, in Nigerian studies have indicated a trend of academic libraries functioning without any ICT policy.

In survey of academic and research libraries in Oyo and Ogun States of Nigeria, "only $6(60.0 \%)$ of the ten libraries studied have ICT policies. The other 4(40.0\%) libraries indicated that they use alternatives, which are not documented, although they all indicated that they have plans to develop ICT policies. .. this also showed that the use of ICT policies by academic and research libraries is quite recent and that they started investing on ICT facilities without functional policy statements.

Besides the need for individual/instructional ICT policy, there is the need to develop an overall national ICT policy for Nigerian academic libraries within which both the private and the government owned academic institution should developed for our academic libraries, continued investment on ICT will be disjointed and thus unable to yield meaningful results. Also, when computer prehensile and coherent policies are developed and presented to potently resources of finding such as ICT 4D (a UN program aimed at promoting ICT for development) additional sources of funding will be accessed.

\section{iii. Poor funding}

Another and perhaps the greatest challenge facing the application of ICT in
Nigerian academic libraries is that of poor funding. This is not on the part of government alone, but also on the part of private owners of academic institutions.

The problem of poor funding is listed by various studies such as Ani et al, 2005; Okiy, 2005; and Ash croft and Watts, 2005, this shows the gravity and centrality of the problem. Poor funding expresses itself in different areas such as poor power supply, poor human resources development, poor state of telecommunication and roller ICT infrastructure and the virtual nonexistence of ICT policies.

Without the necessary funding, none of the other problems facing ICT application in our academic libraries could effectively be solved. Also, without increased funding, all advances such as in human resource development are surely doomed.

\section{CONCLUSION AND RECOMMENDATION}

In spite of the huge problems bedeviling ICT application in the Nigerian academic library setting, the prospects and possibilities are abundant. It is undeniable that much progress has been recoded in ICT application in our academic libraries. However, there is much room for improvement.

For a long lasting, effective and relevant application ICT in Nigerian academic libraries, the following measures are hereby recommended.

- The government must increase the funding of academic institutions. This is imperative seeing that some of the private institutions owners lukewarm attitude is inspired by similar attitude on the part of government. It is only when the funding of academic institutions is increased that the academic libraries in Nigeria will have the required funds to increase that ICT applications and support with local infrastructure such as LAN and local data bases such as electronic cataloguing systems and e-publication.

Even with increased funding, the desire results will not be seen 
Unless comprehensive ITC policies are developed and document as well as published for scrutiny at the national institutional and library levels. These policies will provide a blue print for ICT application and guide the implementers. Only when this is done, will be overall ICT application in Nigerian academic libraries be integrated and made to serve collective goof.

- $\quad$ All said and done, we have the duty collectively and individually to broaden and deepen our ICT skills and explore opportunities of assisting others (colleagues, friends and family) both within and outside the field of ICT and the academic library setting to acquire requisite ICT skills that will help in justifying the huge and continuing investments in ICT.

- Others, even outside the academic institutions and government settings have the responsibility to assist the academic libraries develop and apply relevant ICTs to their processes. To this end, civil society organizations must not be left out; they can take up advocacy and assist in policy articulation and formulation.

Business and other private organization must invest in the future by assisting our academic libraries apply ICT. In the long run, when ICT is successfully applied in the academic library, it s neither the government, the academic libraries, nor the ICT profession and professionals alone that stand to benefit from the fruits of ICT investment in Nigerian academic libraries but the entire country and beyond.

\section{REFERENCES}

ANI, O.E. et al (2005): In the Electronic Library, Emerald Group Publishing Limited Volume 23, Issue, 5, pp 701-708.

ASHOCROFT, L. and WATTS, C. (2005): ICT skills for Information Professionals in Developing Countries: Perspective from a Study of the Electronic Information Environment in Nigeria. In IFLA Journal: International federation of Library Associations and Institutions volume 3. 1(1)pp 6-12.

OKIY, R.B. (2005): Strengthening Information Provision in Nigerian University Libraries through information Communication Technologies in the Electronic Library Emerald Group Publishing limited Volume 23, issue 3, pp 3-318.

ONIYIDE, D.B. (2005): The Internet and World side Web as Resources for Teaching and Learning in schools.

\section{- What is ICT}

hH://searchsmb. Tec target. Com is Definition (2006)

\author{
What is ICT? \\ HHP://www.Tutor \\ 211.net/business/ict/intro. (2006) Lof8:
}

